\title{
Bone Morphogenetic Proteins Induce Astroglial Differentiation of Oligodendroglial-Astroglial Progenitor Cells
}

\author{
P. C. Mabie, M. F. Mehler, R. Marmur, A. Papavasiliou, Q. Song, and J. A. Kessler \\ Departments of Neurology and Neuroscience and the R. F. Kennedy Center for Research in Mental Retardation and \\ Human Development, Albert Einstein College of Medicine, Bronx, New York 10461
}

\begin{abstract}
We have used bipotent postnatal cortical oligodendroglialastroglial progenitor cells $(\mathrm{O}-2 \mathrm{As})$ to examine the role of inductive signals in astroglial lineage commitment. O-2A progenitor cells undergo progressive oligodendroglial differentiation when cultured in serum-free medium, but differentiate into astrocytes in medium supplemented with FBS. We now report that the bone morphogenetic proteins (BMPs), a major subclass of the transforming growth factor $\beta$ (TGF $\beta$ ) superfamily, promote the selective, dosedependent differentiation of O-2As into astrocytes with concurrent suppression of oligodendroglial differentiation. This astroglialinductive action is not sanctioned by other members of the TGF $\beta$ superfamily. Astroglial differentiation requires only very brief initial exposure to the BMPs and is accompanied by increased cellular
\end{abstract}

survival and accelerated exit from cell cycle. Dual-label immunofluorescence microscopy documents that O-2A progenitor cells express a complement of BMP type I and type II receptor subunits required for signal transduction. Furthermore, expression of BMP2 in vivo reaches maximal levels during the period of gliogenesis. These results suggest that the BMPs act as potent inductive factors in postnatal glial lineage commitment that initiate a stable program of astroglial differentiation.

Key words: astrocyte; bone morphogenetic protein; lineage commitment; oligodendrocyte-astrocyte type 2 progenitor; transforming growth factor $\beta$ superfamily; central nervous system development
Normal mammalian CNS development requires the progressive elaboration of diverse, highly specialized cell types that populate the mature brain. The mechanisms underlying this developmental process are not well understood. Studies of the Drosophila nervous system and the mammalian PNS suggest that diversification occurs through progressive lineage restriction of early multipotent progenitors into bipotent and ultimately unipotent precursor cells (for review, see Jan and Jan, 1995) (Anderson, 1989). According to this schema, extracellular signals may play an essential role in development, both as inductive agents at points of lineage restriction and as selective mitogenic or survival factors for stable progenitor or mature cellular populations.

Oligodendrocyte-type 2 astrocyte progenitor cells (O-2As) have been studied in vitro to examine the effects of extracellular signaling on lineage commitment, survival, and proliferation of bipotent neural cells (Raff et al., 1983). Initially cultured from rat optic nerve and later from rat cerebrum (McCarthy and DeVellis, 1980), O-2As are well suited to the study of differentiation, because their development into oligodendrocytes or astrocytes depends on differential environment signals (Temple and Raff, 1985). O-2As are characterized by A2B5 and GD3 immunoreactivity in vitro (Raff et al., 1983; Levison and Gold-

\footnotetext{
Received Sept. 4, 1996; revised Feb. 3, 1997; accepted March 24, 1997.

This work was supported by the Muscular Dystrophy Association and an Irma T. Hirschl Career Scientist Award (M.F.M), and grants from National Institutes of Health (J.A.K.). We thank Steve Pfeiffer and Jim Goldman for providing us with antibody hybridoma cell lines. We thank Anthony Celeste, John Wozney, and Genetics Institute for providing us with BMPs 2 and 4 and the monoclonal antibody to BMP2; and Marc Charette and Creative Biomolecules for providing us with OP1 (BMP7). We thank K. Miyazono for antisera to ALK3, ALK6, and BMPRII. We thank Rick Cohen for technical assistance.

Correspondence should be addressed to Dr. Peter C. Mabie, Department of Neurology, Albert Einstein College of Medicine, Kennedy Center, Room 401, 1300 Morris Park Avenue, Bronx, NY 10461.

Copyright (C) 1997 Society for Neuroscience $0270-6474 / 97 / 174112-09 \$ 05.00 / 0$
}

man, 1993). O-2As cultured in serum-free defined medium proceed through several well-characterized morphological and antigenic developmental stages as they differentiate into mature oligodendroglia, whereas O-2As cultured in FBS develop almost exclusively into astroglia within 3 d (Raff et al., 1983). These observations suggest that for O-2A progenitor cells, the oligodendroglial fate is constitutive, and the astroglial fate requires active induction. Clonal analysis of O-2As that were switched from medium containing 1-10\% FBS revealed the presence of mixed clones containing both oligodendrocytes and astrocytes, demonstrating plasticity of O-2A lineage development (Lubetzki et al., 1992). The astrocyte-inductive factor(s) present in serum has not been identified. Ciliary neurotrophic factor (CNTF) is known to transiently stimulate O-2A glial fibrillary acidic protein (GFAP) expression without ultimately influencing lineage fate (Hughes et al., 1988; Lillien and Raff, 1990). However, CNTF combined with molecules present in the extracellular matrix (ECM) of meningeal or endothelial cells does stably induce the type 2 astrocyte phenotype (Lillien et al., 1990). Interestingly, the ECM-associated molecules inhibit oligodendrocyte differentiation in the absence of CNTF. More recently, leukemia inhibitory factor (LIF) and oncostatin M, two other cytokines that signal through the same gp130/LIF receptor $\beta(\operatorname{LIFR} \beta)$ subunits as $\mathrm{CNTF}$, have been shown to have similar developmental effects (Gard et al., 1995). The $\mathrm{CNTF} / \mathrm{ECM}$ astrocyte-inductive activity is restricted to early $\mathrm{O}-2 \mathrm{As}$ before developing $\mathrm{O} 4$ immunoreactivity, whereas the FBS astrocyte-inductive activity continues through the O4immunoreactive stage of O-2A development (Gard et al., 1995). Several additional cytokines have been identified that promote survival or proliferation of O-2As at various developmental stages. Among these are platelet-derived growth factor (PDGF), basic fibroblast growth factor (bFGF), neurotrophin 
3, and insulin-like growth factor (Barres and Raff, 1994). Additional molecules that support oligodendroglial differentiation include thyroid hormones, retinoic acid, and hydrocortisone (Barres and Raff, 1994).

The study of glial progenitor lineage commitment in vivo has been more difficult (for discussion, see Skoff and Knapp, 1991; Cameron and Rakic, 1991; Levison and Goldman, 1993). Many studies of mammalian embryonic and postnatal progenitors have suggested that proliferative cells of the ventricular zone (VZ) and subventricular zone (SVZ) give rise to progeny predominantly restricted to one lineage (Luskin et al., 1988; Price and Thurlow, 1988). More recently, a study using retroviral labeling of postnatal SVZ cells has found that up to $15 \%$ of labeled clones contained both oligodendroglial and astroglial cell types, compelling in vivo evidence for a bipotent oligodendroglial-astroglial progenitor cell (Levison and Goldman, 1993). This study also noted that the destination of SVZ progenitor migration correlated strongly with the phenotype of the progenitor's progeny, suggesting that environmental signals may play a role in specifying cell fate. The identification of multipotent progenitors from the adult SVZ (Reynolds and Weiss, 1992; Lois and Alvarez-Buylla, 1993) and of O-2As from the adult optic nerve (Wolswijk and Noble, 1992) and cortex (Norton et al., 1988; Gard and Pfeiffer, 1989) suggests that the study of O-2A differentiation may have relevance to models of CNS disease as well as development. Transplantation studies have demonstrated O-2A lineage plasticity by following their fate in vivo. When transplanted into glial-depleted regions of the CNS, O-2As develop into both oligodendrocytes and astrocytes (for review, see Franklin and Blakesmore, 1995). In demyelinating disease, cells have been identified that label with both O-2A (O4) and astrocyte (GFAP)-specific antibodies (Godfraind et al., 1989).

The bone morphogenetic protein (BMP) subclass of the TGF $\beta$ superfamily has only recently gained attention in the study of mammalian CNS development (for review of the TGF $\beta$ superfamily, see Kingsley, 1994; for review of the BMPs, see Hogan, 1996). BMP4 has been implicated in ventral mesoderm induction (Harland, 1994) and is now thought to sanction epidermal and inhibit neural fate during Xenopus gastrulation (Sasai et al., 1995; Wilson and Hemmati-Brivanlou, 1995). In the chick neural tube, dorsal cell fates are induced by BMP4 and/or BMP7 expressed in the overlying epidermal ectoderm (Liem et al., 1995). Dorsal neural tube expression of BMP4 has been implicated in selective apoptosis of hindbrain rhombomeres 3 and 5 (Graham et al., 1994). The BMPs have been implicated in several aspects of neural crest progenitor differentiation, including neuronal lineage commitment (Shah et al., 1996) and the acquisition of the adrenergic phenotype (Reissmann et al., 1996). In the rodent, BMP4 and BMP6 are expressed in early embryonic brain (Jones et al., 1991; Schluesener and Meyermann, 1994). Mice deficient in BMP2 and BMP4 show early embryonic lethality (Winnier et al., 1995; Hogan, 1996), whereas mice deficient in BMP7 have developmental abnormalities of the eyes and kidneys (Dudley et al., 1995; Luo et al., 1995).

BMP ligands signal as homodimers or heterodimers that interact with at least two receptor subunits, called type I and type II (Kingsley, 1994; ten Dijke et al., 1994a,b). Studies with transfected COS cells suggest that high-affinity binding may occur between the ligands BMP4 and BMP7 and a type I receptor alone but is enhanced by the presence of a type II receptor (ten Dijke et al., 1994c). In Drosophila, the BMP homolog decapentaplegic re- quires the presence of both type I and type II receptor subunits for active signal transduction (Letsou et al., 1995, Ruberte et al., 1995). There are currently three BMP type I receptors identified and cloned, initially called activin receptor-like kinases (ALKs) 2, 3 , and 6 , based on homology to the activin type I receptor (ten Dijke et al., 1994a,b,c). ALKs 3 and 6 bind BMPs but not activin or any other known TGF $\beta$ factors (ten Dijke et al., 1994c); thus, they have been called BMP type I receptors Ia and Ib. A type II receptor specific for the BMPs has also been cloned (BMPRII) (Rosenzweig et al., 1995). Each of these receptors is expressed in the developing mouse brain (ten Dijke et al., 1994b,c; Rosenzweig et al., 1995). Mice deficient in BMPR Ia die before gastrulation (Mishina et al., 1995).

\section{MATERIALS AND METHODS}

$O-2 A$ cultures. Rat postnatal day 2 (P2) cortex was dissected and dissociated mechanically by repeated trituration in DMEM/F12 1:1 supplemented with $10 \%$ FBS, glucose $(6 \mathrm{mg} / \mathrm{ml})$, and glutamine $(2 \mathrm{~mm})$, and then filtered through a $60 \mu \mathrm{m}$ Nytex filter. Cells were then pelleted, resuspended, and plated onto poly-D-lysine (PDL, $20 \mu \mathrm{g} / \mathrm{ml}$ for $1 \mathrm{hr}$ )coated T75 flasks at 1.5 brains per flask. Cultures were fed twice per week, and $\sim 2 \mathrm{~d}$ after reaching confluence (total of 9-10 $\mathrm{d}$ in vitro), flasks were shaken for $3 \mathrm{hr}$ at $250 \mathrm{rpm}$ to remove microglia, refed, and then shaken overnight at $300 \mathrm{rpm}$ to remove O-2As. Collected O-2As were further purified by passing through a $60 \mu \mathrm{m}$ Nytex filter and preplating on uncoated plastic dishes for $2 \mathrm{hr}$ to remove contaminating microglia. Cells were then pelleted, resuspended in serum-free medium (SFM), counted, and plated at $\sim 10^{4}$ cells per well in PDL-coated 24-well plates. SFM consisted of DMEM/F12 (1:1) with glucose $(6 \mathrm{ng} / \mathrm{ml})$, glutamine $(2 \mathrm{mM})$, BSA $(0.1 \mathrm{mg} / \mathrm{ml})$, transferrin $(50 \mu \mathrm{g} / \mathrm{ml})$, triiodothyronine $(30 \mathrm{nM})$, hydrocortisone $(20 \mathrm{nM})$, progesterone $(20 \mathrm{nM})$, biotin $(10 \mathrm{nM})$, selenium (30 nM), and insulin $(5 \mu \mathrm{g} / \mathrm{ml})$. For $48 \mathrm{hr}$ before experimental manipulation, bFGF $(2.5 \mathrm{ng} / \mathrm{ml})$ and PDGF AA $(2.5 \mathrm{ng} / \mathrm{ml})$ were added. Some cells were grown on $9 \mathrm{~mm}$ glass coverslips coated with PDL for dual-label immunofluorescent analysis. Cells were maintained in a humidified incubator with $5 \% \mathrm{C} 02$ at $37^{\circ} \mathrm{C}$. Control cultures were fed every $2 \mathrm{~d}$, and BMP-treated cultures received fresh medium and growth factors every $4 \mathrm{~d}$. O-2A cultures analyzed at the beginning of the experimental manipulation contained at least $95 \%$ cells immunoreactive to the O-2Aassociated antibodies GD3 and A2B5.

Immunocytochemistry. At the designated time, SFM was withdrawn and cells were fixed with ice-cold absolute methanol for $10 \mathrm{~min}$. For GD3, $\mathrm{A} 2 \mathrm{~B} 5, \mathrm{O} 4$, and galactocerebroside immunocytochemistry, cells were incubated with antibodies for $30 \mathrm{~min}$ at $4^{\circ} \mathrm{C}$, followed by washing and fixing. After treatments with $0.3 \% \mathrm{H}_{2} \mathrm{O}_{2}$ for 20 min and blocking serum $(5 \%$ goat serum) for $30 \mathrm{~min}$, primary antibodies to intracellular antigens were applied for $2 \mathrm{hr}$ at room temperature. Appropriate biotinylated secondary antibodies (Vector Laboratories, Burlingame, CA) were applied at 1:200 dilution for $30 \mathrm{~min}$, followed by application of the $\mathrm{ABC}$ reagent (Vector) for $1 \mathrm{hr}$. The peroxidase reaction was performed with visualization of label using diaminobenzidine $0.5 \mathrm{mg} / \mathrm{ml}$ as substrate in $50 \mathrm{~mm}$ Tris, $\mathrm{pH}$ 7.6, containing $0.01 \% \mathrm{H}_{2} \mathrm{O}_{2}$ for $5 \mathrm{~min}$. All steps were followed by washes in PBS, pH 7.4, except the blocking serum step. For analysis of bromodeoxyuridine (BrdU) incorporation, cells were pulsed with $1 \mu \mathrm{M} \mathrm{BrdU}$ for $24 \mathrm{hr}$ before fixation, and cells were treated with $2 \mathrm{~N} \mathrm{HCl}$ for $30 \mathrm{~min}$ and sodium borate, $\mathrm{pH} 8$, for $10 \mathrm{~min}$ before application of blocking serum. For dual-label immunofluorescence, cells grown on coverslips were incubated with primary antibodies as above and then incubated with the appropriate fluoroscein and rhodamine-conjugated secondary antibodies (Southern Biotechnology, Alabaster, AL) at 1:100 dilution for $1 \mathrm{hr}$; coverslips were mounted onto glass slides using a Molecular Probe (Eugene, OR) anti-fade mounting kit following the manufacturer's protocol. Controls were performed without primary antibody, with alternate primary antibodies, and with inappropriate secondary antibodies, and showed negligible background.

Western blot. Protein samples were prepared by manually homogenizing the whole brains of $\mathrm{P} 8$ and adult mice in $50 \mathrm{~mm}$ Tris-Cl, $0.15 \mathrm{M} \mathrm{NaCl}$, pH 7.6, containing $10 \%$ glycerol, $0.1 \%$ NP-40, $0.1 \%$ Triton X-100, $0.1 \%$ SDS, $1 \mathrm{~mm}$ PMSF, and $0.3 \mathrm{~mm}$ sodium orthovanadate (lysis buffer). After centrifugation, samples were quantitated by the Micro BCA Protein Assay method (Pierce, Rockford, IL) following the manufacturer's protocol. Samples were resolved by SDS-PAGE on $10 \%$ acrylamide gels 


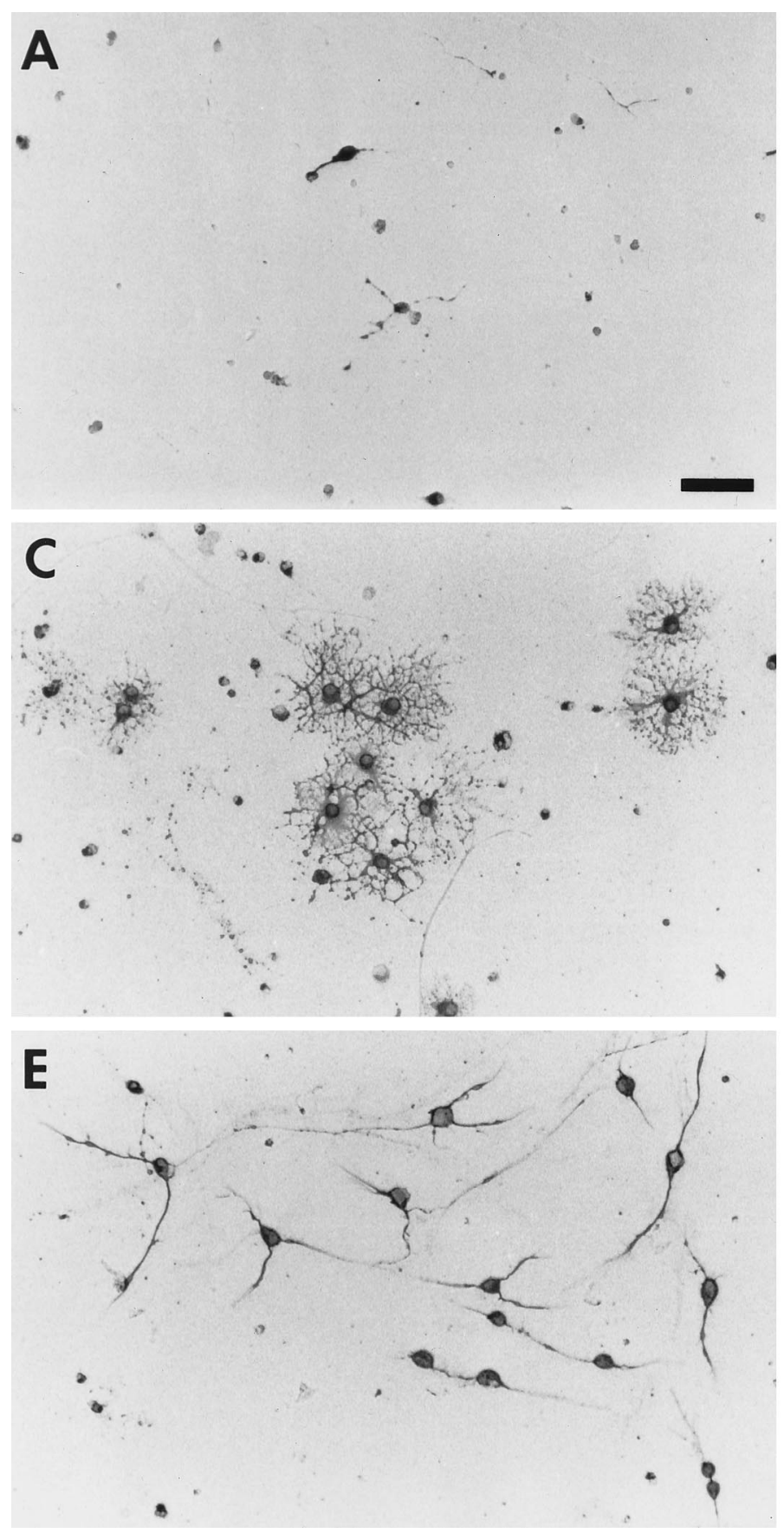

(Bio-Rad ready-made, Hercules, CA) using a Mini-PROTEAN II system (Bio-Rad) at $85 \mathrm{~V}$, and then transferred by immersion at $300 \mathrm{~mA}$ overnight onto nitrocellulose membranes. BMP2 was detected using a mouse monoclonal antibody to BMP2 diluted 1:1500 in PBS containing $5 \%$ nonfat dried milk (Blotto) for $4 \mathrm{hr}$ at room temperature, followed by incubation with a horseradish peroxidase-conjugated secondary antibody (Amersham, Arlington, Heights, IL) diluted 1:1500 in Blotto for $1 \mathrm{hr}$ at room temperature, visualized using the ECL method (Amersham), exposed to Kodak (Rochester, NY) x-ray film (5-15 min), and developed in a Kodak automatic developer.

Antibodies. Antibody preparations included monoclonal anti-GFAP (1:500; Sigma, St. Louis, MO), monoclonal anti-BrdU (1:400; Novocastra Laboratories), monoclonal anti-galactocerebroside (GC/O1) and monoclonals $\mathrm{A} 2 \mathrm{~B} 5$ and $\mathrm{O} 4$ (supernatants from mouse hybridomas O1, A2B5, and O4, 1:2; the gift of S. Pfeiffer, University of Connecticut), monoclonal GD3 (supernatant from mouse hybridoma, 1:2; the gift of J. Goldman, Columbia University), affinity-purified rabbit poly-

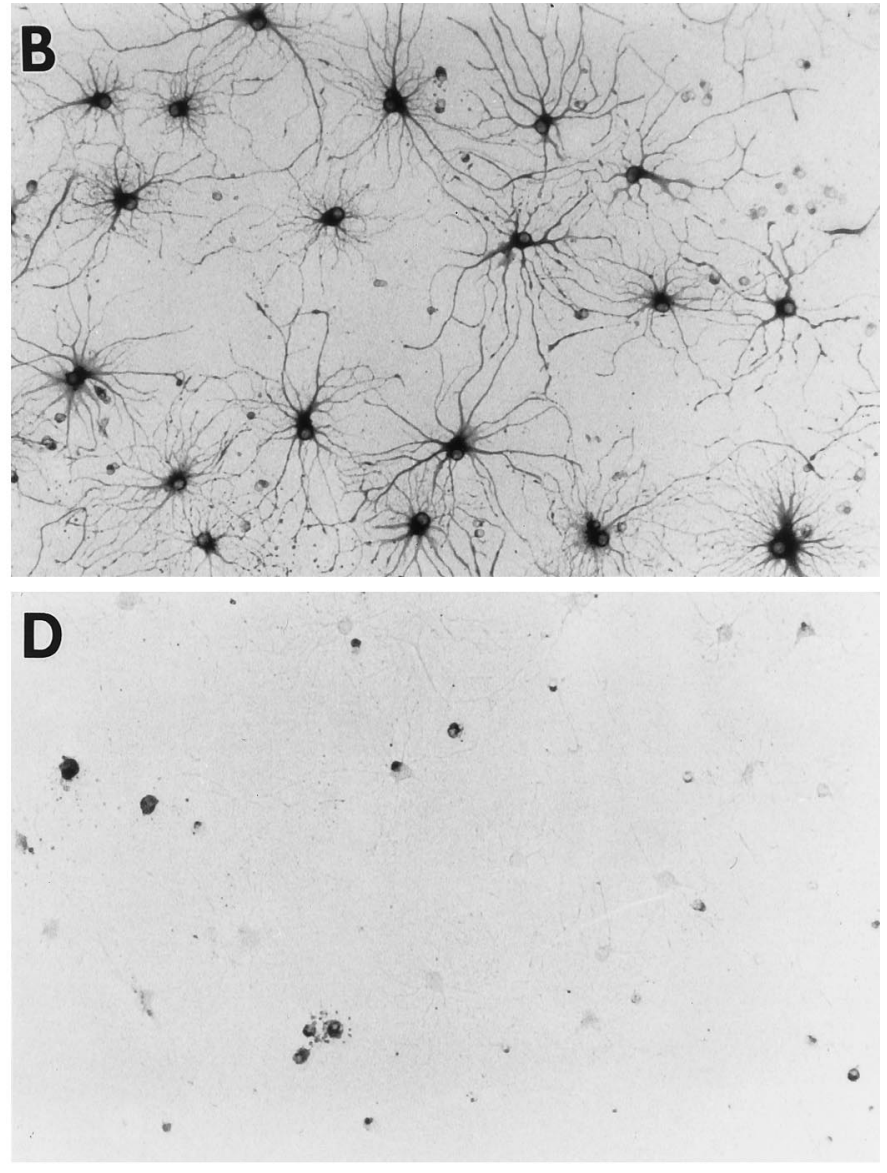

Figure 1. Effect of BMP2 on O-2A differentiation. Photomicrographs of O-2As grown for $4 \mathrm{~d}$ with no added growth factor $(A, C)$ or BMP2 $(10$ $\mathrm{ng} / \mathrm{ml})(B, D)$ and labeled with anti-GFAP $(A, B)$ or GC/O1 $(C, D) . E$, Photomicrograph of O-2A cells at the start of experimental manipulation labeled with anti-GD3. Scale bar, $65 \mu \mathrm{m}$.

clonal antisera to ALK3, ALK6, and BMPRII (SMN) (each at 1:100; the gifts of K. Miyazono, The Cancer Institute, Tokyo), and monoclonal anti-BMP2 (1:1500; the gift of A. Celeste, Genetics Institute, Cambridge, MA).

Growth factors. Recombinant human BMPs 2 and 4 were provided by A. Celeste and J. Wozney, Genetics Institute. Recombinant human BMP7 (OP1) was provided by Marc Charette and Creative Biomolecules, Cambridge, MA. BFGF and PDGF were obtained from Collaborative Biomedical, Bedford, MA.

Quantification. Cell counts per well were calculated by counting representative fields of view making up one quarter of the total culture well area and multiplying by 4 . Each experimental value represents the mean \pm SEM of three replicate culture wells. Similar results were obtained in experiments from two additional cellular preparations performed in triplicate. Significance was determined by one-way ANOVA and the unpaired $t$ test; ${ }^{*} p \leq 0.05,{ }^{*} p \leq 0.01$, and ${ }^{* *} p \leq 0.001$. 


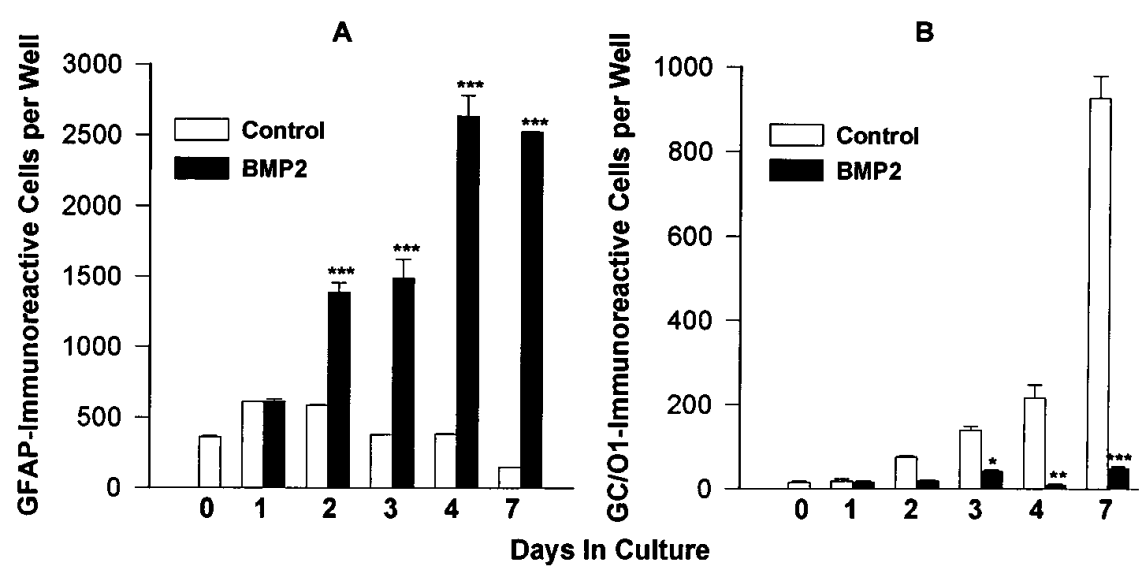

Figure 2. Development of O-2A progenitors in the absence or presence of BMP2 $(10 \mathrm{ng} / \mathrm{ml})$. O-2As in SFM were analyzed for GFAP $(A)$ or $\mathrm{GC} / \mathrm{O} 1(B)$ immunoreactivity at days $1-4$ and 7 .

\section{RESULTS}

Bone morphogenetic proteins promote $0-2 \mathrm{~A}$ differentiation into astrocytes and suppress oligodendroglial differentiation

Cultures of O-2As grown in SFM contained cells that began as $\geq 95 \%$ A2B5-immunoreactive and $\geq 75 \%$ O4-immunoreactive that over time displayed increasing numbers of GC-immunoreactive oligodendrocytes (Figs. 1, 2B). The number of GFAP-immunoreactive astrocytes declined over $7 \mathrm{~d}$ (Fig. $2 A$ ). As described previously (Raff et al., 1983), O-2As grown in FBS-supplemented medium developed into a near-uniform population of GFAP-immunoreactive astrocytes within $3 \mathrm{~d}$, with very few oligodendrocytes (data not shown). Treatment of O-2As with BMP2 $(10 \mathrm{ng} / \mathrm{ml})$ in SFM promoted the development of GFAP-immunoreactive astroglia (Figs. 1, 2A), while suppressing O-2A development into GC-immunoreactive oligodendroglia (Figs. 1, 2B). BMP treatment also suppressed the development of cells expressing myelin 2',3'-cyclic nucleotide $3^{\prime}$ phosphodiesterase (myelin CNPase) and the oligodendrocytespecific isoform of glutathione-S-transferase (data not shown). This effect was accompanied by an increase in survival of O-2As as determined by an increase in the number of total cells (total cell counts after 4 d: control, $1199 \pm 174$; BMP2-treated, $2739 \pm 241$, $n=3, p<.01$ ), despite a decrease in proliferation (Fig. 3). In both conditions, $\geq 95 \%$ of cells were A2B5-immunoreactive; in the control condition, $\geq 80 \%$ were O4-immunoreactive cells, whereas in the BMP2 condition, only $50-60 \%$ of the cells were O4immunoreactive. Dual-label immunofluorescent analysis demonstrated that a subset of GFAP-immunoreactive cells also expressed weak O4-immunoreactivity after $4 \mathrm{~d}$ of BMP2 treatment; however O4-immunoreactivity is lost by $7 \mathrm{~d}$ (data not shown). These observations suggest that the BMP oligodendrocyte-suppressive effect was not the result of increased death of oligodendrocytes or their precursors but of differentiation of O-2As into astrocytes.

\section{BMPs promote 0-2A progenitor cell exit from cell cycle}

An increase in the number of a given cell type may occur by enhanced survival, proliferation, and/or differentiation of a precursor population. TGF $\beta$ signals are known to sanction each of these developmental effects in vitro (Kinglsey, 1994), depending on the cell types studied. Epidermal growth factor-responsive mouse embryonic cells co-treated with the BMPs are less active mitotically than are parallel cells grown in EGF alone (D'Alessandro and Wang, 1994). On the other hand, primary embryonic cortical cells and conditionally immortalized hippocampal progenitor cells cultured in serum-free conditions, in

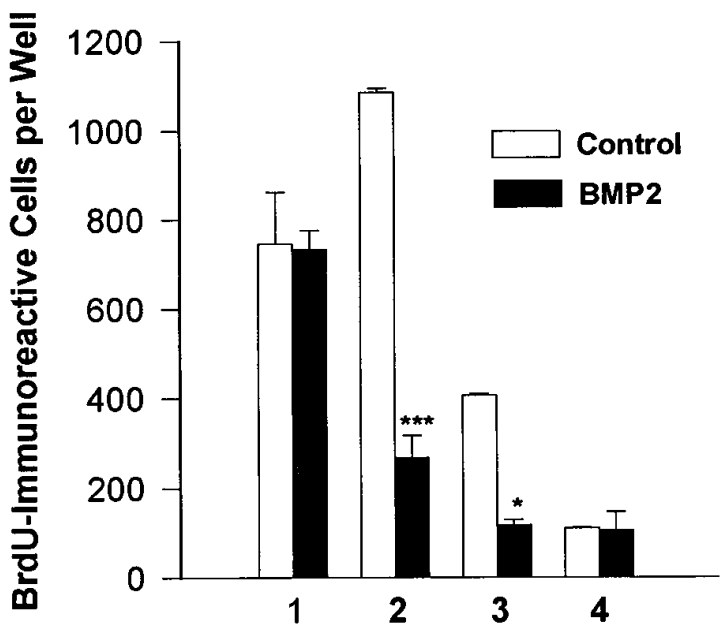

Figure 3. Effect of the BMPs on O-2A proliferation. O-2As treated with no added growth factor or BMP2 $(10 \mathrm{ng} / \mathrm{ml})$ were analyzed for BrdU incorporation by immunocytochemistry on 4 successive days.

which proliferation is very limited, respond to BMP treatment with an early increase in proliferation that subsides after $2 \mathrm{~d}$ (our unpublished observations). Unlike type 1 astrocytes, which are thought to divide several times after acquiring their mature morphological and antigenic phenotype, type 2 astrocytes are thought to terminally differentiate at the time they exit from cell cycle (Lillien and Raff, 1990). To determine the effect of the BMPs on $\mathrm{O}-2 \mathrm{~A}$ proliferation, untreated and BMP-treated (BMP2, $10 \mathrm{ng} /$ $\mathrm{ml}$ ) O-2A progenitor cells were analyzed for BrdU incorporation on four successive days. During the first and fourth days, there was no significant difference between control and BMP-treated groups; however, during the second and third days, BMP2 treatment significantly decreased the number of proliferating cells (Fig. 3). To define further the phenotype of proliferating cells in these cultures, dual-label immunofluorescent analysis was performed on control and BMP2-treated cultures. After a $24 \mathrm{hr}$ BrdU pulse, all BrdU-immunoreactive cells were A2B5immunoreactive, and not galactocerebroside or GFAPimmunoreactive, in both the control and BMP2-treated cultures (data not shown). Given that BMP treatment decreases proliferation while simultaneously increasing the total number of O-2As and GFAP-immunoreactive cells (see above) (Fig. 2A), these results demonstrate that BMPs enhance survival and astrocytic differentiation of O-2As and not the proliferation of committed astroblasts. Consistent with the effects of FBS, BMP-generated 
A

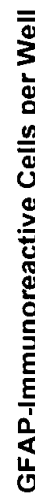

Figure 4. O-2A dose responses to BMPs 2, 4, and 7. $\mathrm{O}-2 \mathrm{As}$ treated with no added growth factor or BMPs 2,4 , or 7 at $0.1,1,10$, or $30 \mathrm{ng} / \mathrm{ml}$ were grown for $4 \mathrm{~d}$ and analyzed for GFAP $(A)$ and $\mathrm{GC} / \mathrm{O} 1 \quad(B)$ immunoreactivity.

astrocytes differentiate earlier than oligodendrocytes, suggesting that $\mathrm{O}-2 \mathrm{~A}$ lineage fate is determined by the availability of signals rather than by the ability to respond to these signals (Raff, 1989).

\section{BMP effects on astrocyte induction are dose- dependent and are not mimicked by other members of the TGF $\beta$ superfamily}

TGF $\beta$ cytokines have been shown to have complex patterns of expression in the CNS and to have different effects depending on the specific ligand, concentration, and cell type studied (Flanders et al., 1991; Poulsen et al., 1994). To investigate the specificity of the effects demonstrated with BMP2 on O-2A progenitor cells, O-2A cultures were treated with no added growth factor, with factors from two distinct BMP subclasses, or with members of three other TGF $\beta$ subclasses [TGF $\beta 1$, activin, and glial-derived neurotrophic factor (GDNF)]. After $4 \mathrm{~d}$ in culture, BMPs 2, 4, and 7 each displayed potent dose-dependent potentiation of the number and morphological differentiation of GFAP-immunoreactive astrocytes, with suppression of the number of GC-immunoreactive oligodendrocytes (Fig. 4). BMPs 2 and 4 exhibited similar efficacy at $\geq 10 \mathrm{ng} / \mathrm{ml}$, but differed at $1 \mathrm{ng} / \mathrm{ml}$, in which BMP4 was more potent both in astrocyte induction and oligodendrocyte suppression. BMP7 was somewhat less efficacious in both astrocyte induction and oligodendrocyte suppression. Preliminary studies with other BMP family members demonstrate a similar range of effects (data not shown). In contrast to the BMPs, TGF $\beta 1$, activin, and GDNF, representatives of three distinct TGF $\beta$ subclasses, failed to promote astroglial development (Fig. 5). These observations suggest that the astroglial-inductive effects are specified by a discrete subset of TGF $\beta$ superfamily cytokines known to share common receptor subunits.

\section{Responsiveness to the BMPs is temporally and developmentally regulated}

Developing SVZ progenitor cells are exposed to changing microenvironments as they begin to migrate out of the SVZ. As a result, progenitor cells may be exposed to a given extracellular signal for only a brief period of time. Furthermore, cells of the same lineage may gain or lose responsiveness to a given extracellular signal as they progress through different developmental stages. To examine whether continuous exposure to the BMPs is required to maintain the astroglial phenotype, O-2As were treated with BMP2 (10 $\mathrm{ng} / \mathrm{ml}$ ) for various temporal intervals, and then placed in SFM without BMPs for the remainder of the observation period. BMP treatment for one $\mathrm{hr}$ was sufficient to increase the number of astrocytes 5-fold and decrease the number of oligodendrocytes more than three-fold (Fig. 6A). Astrocytes generated after brief BMP application displayed a mature morphological and antigenic

B

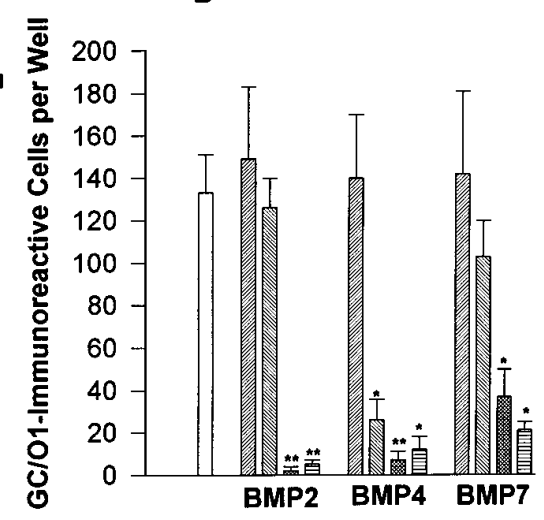

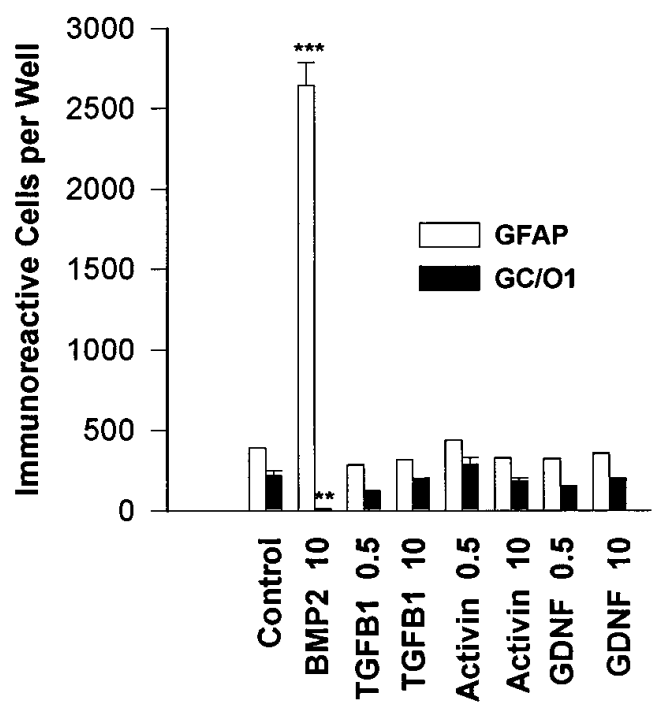

Figure 5. Comparison of BMP effects with other TGF $\beta$ cytokines. O-2As were treated with TGF $\beta 1$, activin, or GDNF $(0.5$ or $10 \mathrm{ng} / \mathrm{ml})$ for $4 \mathrm{~d}$, analyzed for GFAP and GC/O1 immunoreactivity, and compared with control and BMP2 $(10 \mathrm{ng} / \mathrm{ml})$-treated cultures.

phenotype similar to cells continuously treated with the BMPs. Increasing the BMP exposure time resulted in a greater number of GFAP-immunoreactive astrocytes and fewer GC-immunoreactive oligodendrocytes, with exposure for $96 \mathrm{hr}$ resulting in maximal trophic effects. Thus the predominant effect of the BMPs is on the establishment of the astroglial phenotype rather than the maintenance of it.

Given that O-2As undergoing terminal differentiation exit from cell cycle and are no longer susceptible to the astroglial-inductive effects of FBS, we predicted that delaying O-2A BMP treatment would attenuate the astrocyte-inductive and oligodendrocytesuppressive effects. To examine whether O-2A responsiveness to the BMPs changes during development, O-2As were initially cultured in SFM without added growth factors to allow progression through sequential oligodendroglial developmental stages and were then treated after variable time intervals $(24,48$, and 96 hr) with BMP2 $(10 \mathrm{ng} / \mathrm{ml})$. Our results indicate that as O-2As differentiate in SFM toward postmitotic oligodendrocytes, their responsiveness to the BMPs is attenuated (Fig. 6B). Even with delayed addition at $96 \mathrm{hr}$, however, BMP treatment increases significantly the number of GFAP-immunoreactive cells and decreases the number of GC-immunoreactive cells that develop (compare Fig. $6 B$ with Fig.2A,B). These results suggest that the 
A

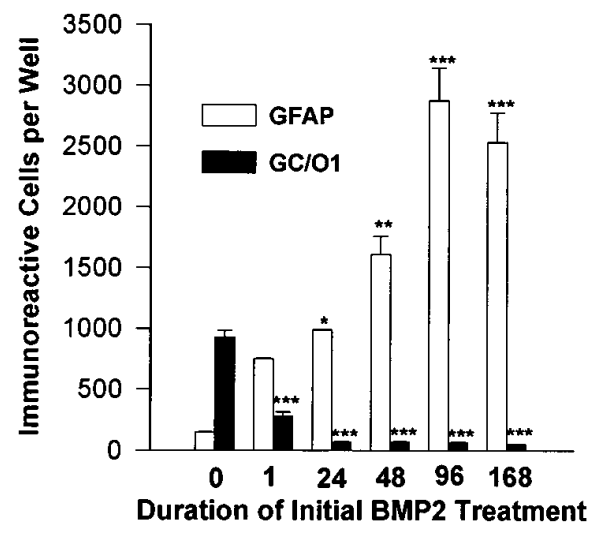

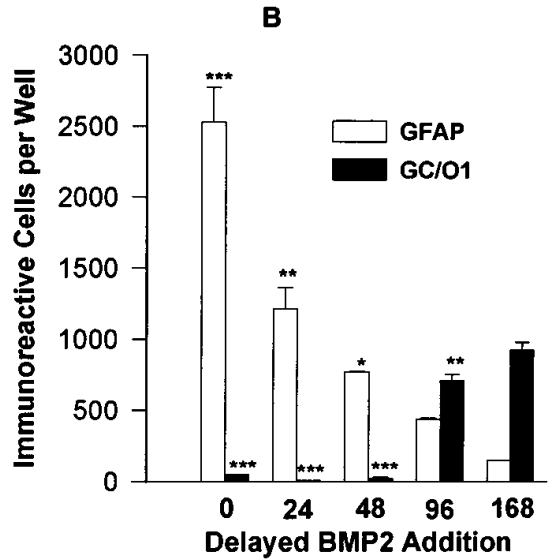

Figure 6. The effects of altered timing of BMP treatment on O-2A differentiation. $A$, Early withdrawal; cultures were treated with BMP2 $(10 \mathrm{ng} / \mathrm{ml})$ at the start of the experiment for $1,24,48$, or $96 \mathrm{hr}$, washed three times, and replaced in SFM for the remainder of the experimental period. Controls remained untreated or treated with BMP2 $(10 \mathrm{ng} / \mathrm{ml})$ throughout the experimental period. After $7 \mathrm{~d}$, cultures were analyzed for GFAP and GC/O1 immunoreactivity. $B$, Late addition; cultures were treated with BMP2 (10 $\mathrm{ng} / \mathrm{ml}$ ) after variable delays of 24,48 , or $96 \mathrm{hr}$ and were analyzed as in $A$, using the same controls.
BMPs operate maximally when the majority of cells are actively proliferating and that a brief early exposure to the BMPs has a lasting effect on the establishment and maintenance of the differentiated astroglial phenotype.

\section{BMP receptors are expressed by 0 -2As}

Given the uniform response of O-2As to the BMPs, we predicted that O-2A progenitor cells would express type I and type II BMP receptor subunits. To examine the expression of BMP receptors, we analyzed O-2A progenitors by dual-label immunofluorescence with antibodies that recognize O-2As (A2B5 and O4) and affinitypurifed polyclonal antibodies to BMP type I receptor subunits BMPRIa and BMPRIb and the type II receptor subunit BMPRII. Virtually all cells immunoreactive to the O-2A-specific antibody O4 expressed BMPRII (Fig. 7B) and BMPRIb (Fig. 7D); the majority also expressed BMPRIa (Fig. $7 F$ ). Identical results were seen with A2B5-immunoreactive cells (data not shown). Furthermore, BMP receptor subunits were not expressed by any nonO-2A contaminating cells that were present (e.g., A2B5-negative or O-4-negative cells). Expression of the transcripts for these receptor subunits was also demonstrated by RT-PCR (data not shown). Thus, the BMP receptor subunits that are necessary for BMPdirected signal transduction are expressed by O-2As, suggesting that BMP astrocyte induction represents a direct cellular effect on this progenitor population.

\section{BMP expression in vivo is developmentally regulated}

For the BMPs to play a role in glial development in vivo, both ligand and receptor subunits must be expressed at the appropriate time to mediate the proposed developmental effects. To determine whether the expression of the BMPs is developmentally regulated, we examined BMP2 expression in $\mathrm{P} 8$ and adult brain by Western blot. Expression of BMP2 is significantly higher during the period of gliogenesis than it is in the adult (Fig. 8). Thus, BMP ligand is expressed in the brain at a time when bipotent glial progenitor cells are beginning to differentiate and may be susceptible to the lineage-inductive effects of the BMPs demonstrated in vitro.

\section{DISCUSSION}

\section{Identification of a class of cytokines that promote astroglial lineage commitment}

Epigenetic signals that influence CNS lineage commitment remain largely undefined. Previous work has identified several signals that modulate the proliferation and survival of $\mathrm{O}-2 \mathrm{~A}$ progenitor cells and that promote oligodendroglial differentiation of these bipotent glial progenitors. The development of O-2As into astrocytes, however, has required undefined inductive signals in FBS or meningeal ECM plus CNTF. We now report that the BMPs, a subclass of the TGF $\beta$ superfamily, promote astroglial differentiation and suppress oligodendroglial differentiation of oligodendroglial-astroglial progenitor cells. These dose-dependent effects are BMP subclass-specific and implicate specific signal transduction pathways mediated by BMP ligand-receptor subunit interactions.

The genesis of astrocytes has been the topic of much debate over the past 15 years. Two models of gliogenesis were initially proposed, one based largely on in vitro studies of optic nerve, and the other on $\left[{ }^{3} \mathrm{H}\right]$ thymidine and retroviral labeling studies in vivo. In the first model, astrocytes were proposed to develop during two periods, an embryonic period, during which protoplasmic astrocytes arise from the conversion of radial glia, and a postnatal period, during which bipotent oligodendroglial-astroglial progenitors are induced to differentiate into stellate astrocytes by environmental cues. O-2A progenitors were proposed to be the in vitro equivalent of the bipotent glial progenitor cell in vivo. This model has been questioned because of the failure to identify cells in vivo that co-express A2B5 and GFAP immunoreactivity and the initial failure to detect a progenitor, the in vivo progeny of which includes both astrocytes and oligodendrocytes (see Goldman et al., 1986; Curtis et al., 1988; Lillien and Raff, 1990; Cameron and Rakic, 1991; Skoff and Knapp, 1991). The second model proposed that progenitor cells within the embryonic VZ and SVZ are already committed to a specific fate. Although a consensus has not yet been reached, several recent observations suggest a model of gliogenesis that integrates aspects of both earlier models. First, the recent identification of neonatal SVZ progenitors that give rise to both oligodendrocytes and astrocytes (Levison and Goldman, 1993) has renewed interest in signals that may influence postnatal bipotent glial progenitor fate. A role for such regulated environmental cues is suggested by the interesting observation that the destination and timing of SVZ progenitor migration appear to correlate with the ultimate phenotype of the progenitor's progeny. Cells that migrate into gray matter tend to differentiate into astrocytes, and cells that migrate into white matter tend to differentiate into oligodendrocytes. Second, astrocytes derived from O-2A progenitors lose A2B5 immunoreactivity over time in culture (Lillien and Raff, 1990; our unpublished observation), suggesting that A2B5 immunoreactivity may reflect the influence of the isolation and culture procedures, but may not be an appropriate criterion for classifying astrocytes into two types. Thus, A2B5 immunoreactivity may not identify the astrocytic 

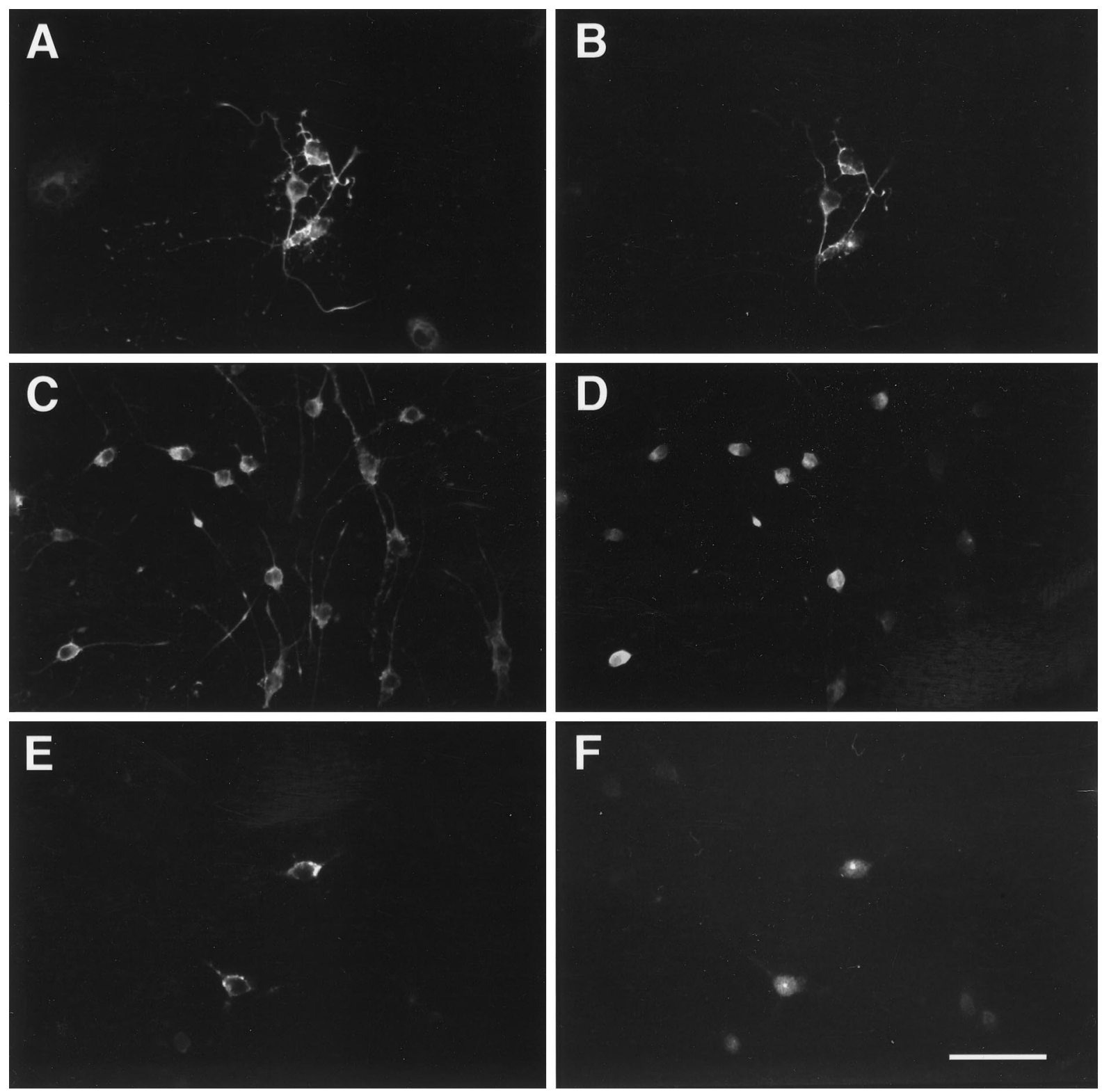

Figure 7. O-2A expression of BMP type I and type II receptor subunits. Photomicrographs of immunofluorescent dual-labeled O-2As with the lineage-specific antibody $\mathrm{O} 4(A, C, E)$ and antisera to BMPRII $(B)$, BMPRIb $(D)$, and BMPRIa $(F)$. Each pair $(A, B ; C, D ; E, F)$ represents the same field of view. Scale bar, $65 \mu \mathrm{m}$.

progeny of a bipotent glial progenitor in vivo. The identification of multipotent and bipotent neural progenitors that persist into adulthood (Norton et al., 1988; Gard and Pfeiffer, 1989; Wolswijk and Noble, 1989; Reynolds and Weiss, 1992; Schwartz and Wilson, 1992; Lois and Alvarez-Buylla, 1993) suggests that environmental signals may continue to influence the fate of uncommitted progenitor cells throughout postnatal life.

Our finding that the BMPs induce astroglial differentiation and suppress oligodendroglial development of oligodendroglialastroglial progenitors in vitro demonstrates that the BMPs may regulate postnatal astrocytic lineage commitment of glialrestricted bipotent progenitor cells. The BMP ligands and receptor subunits are expressed in the developing CNS at the appropriate time to play such a role in vivo. We have also confirmed that $\mathrm{O}-2 \mathrm{As}$ express BMP receptors in vitro. Other studies have suggested that the BMPs may also promote astrocytic lineage com- mitment and/or differentiation at an earlier embryonic developmental stage in cells that express very low or no A2B5 immunoreactivity (D'Alessandro et al., 1994; Gross et al., 1996). Additional support that the BMPs may regulate neural lineage commitment comes from the recent report that the BMPs specify the neuronal fate in multipotent neural crest progenitor cells (Shah et al., 1996).

Previous investigations of $\mathrm{O}-2 \mathrm{~A}$ differentiation have used undefined factors in FBS, or meningeal ECM plus CNTF, to induce the astroglial phenotype. Our results with the BMPs mimic FBSinduced astroglial differentiation both temporally and developmentally and contrast with the effects of CNTF with or without meningeal ECM. The BMP effect on O-2A morphology and antigenic phenotype, like FBS, is apparent at 48-72 hr and persists. CNTF causes transient expression of GFAP in a minority of cells at $24 \mathrm{hr}$, with loss of GFAP-immunoreactivity and develop- 
P8

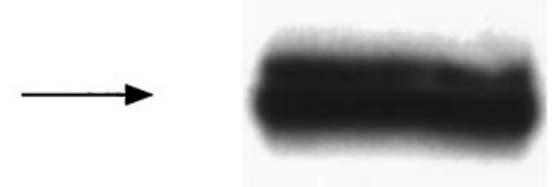

Adult

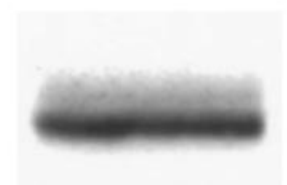

Figure 8. Expression of BMP2 in P8 and adult brain. Western blots were performed with a monoclonal antibody specific for BMP2. $\rightarrow$ Indicates the $116 \mathrm{kDa}$ (unprocessed) form of BMP2.

ment into oligodendrocytes by 72 hr (Hughes et al., 1988). Thus, $\mathrm{CNTF}$ alone does not influence O-2A lineage fate. When combined with unidentified molecules in meningeal or endothelial ECM, CNTF results in the stable induction of the astroglial phenotype (Lillien et al., 1990). The BMPs, like FBS, appear to induce astrocytes at both pre-O4 and O4-immunoreactive developmental stages, whereas meningeal ECM plus CNTF or LIF only induces astrocytes at the pre-O4 stage (Gard et al., 1995). Because serum contains endogenous BMP ligand (Perides et al., 1994), the BMPs may largely mediate the astrocyte-inductive effects of serum. The astrocytes that develop in the presence of the BMPs are similar phenotypically to those grown in FBS, including a subpopulation that co-expresses O4/GFAP immunoreactivity. BMPgenerated astrocytes differ, however, in that they appear to lose A2B5 immunoreactivity more rapidly than those grown in FBS (data not shown). If the BMPs are, in fact, an inductive signal for astrocytic lineage commitment in vivo, this may explain partially the difficulty in detecting A2B5/GFAP dual-immunoreactive cells in vivo.

\section{Temporal/developmental window of BMP effects}

Brief exposure to the BMPs is sufficient to initiate an astroglial lineage program that is sustained without additional dependence on the presence of exogenous BMPs. Extended treatment intervals cause an increase in the number of cells induced to the astroglial phenotype. Such trophic actions imply the presence of an astrocyte differentiation switch that can be constitutively activated with a brief stimulus. Work in the PNS has suggested such a role for glial growth factor, a ligand of the neuregulin family (Shah et al., 1994). The concept that the BMPs play a role in neural lineage commitment is supported by the recent report that the BMPs specify the neuronal fate in multipotent neural crest progenitor cultures (Anderson, 1996). The identification of the nuclear protein encoded by the gene glial cells missing in Drosophila that acts as a binary switch controlling neuronal versus glial fate presents a potential downstream mechanism for such lineageinductive effects (Hosoya et al., 1995; Jones et al., 1995). The BMP signal transduction pathway may stimulate expression of such a switch that once activated, positively regulates astroglial lineage commitment. Survival of committed astrocytes may occur by autocrine signaling mechanisms using BMP or other signals or may occur autonomously.

Experiments with delayed BMP treatment suggest a gradual but progressive loss of $\mathrm{O}-2 \mathrm{~A}$ bipotency and $\mathrm{BMP}$ responsiveness that coincides with cell cycle exit and oligodendroglial terminal differentiation. The mechanisms that mediate the cellular transitions from proliferative, bipotent, and BMP responsive to postmitotic, unipotent, and BMP unresponsive are unknown. TGF $\beta$ cytokines are thought to inhibit proliferation through regulation of cyclindependent kinase inhibitors (Hannon and Beach, 1994). The relationship between cell cycle regulatory proteins and lineage restriction in neural cells has not been investigated. By demonstrating accelerated cell cycle exit with astroglial differentiation, our results suggest that the BMPs co-regulate proliferative capacity and lineage induction.

How these findings relate to in vivo development remains to be determined. Establishment of an astrocyte-inductive role for the BMPs in normal neural development is plausible given the in vivo expression of BMP ligands and receptor subunits and the identification of potentially responsive bipotent progenitor cells in vivo. This hypothesis will require validation in an in vivo model in which BMP signal transduction can be both positively and negatively manipulated without resulting in early lethality. With the increasing appreciation of immature cells present in the adult SVZ and subcortical white matter (Gensert and Goldman, 1996), a possible role for the BMPs also exists within several pathological contexts. TGF $\beta$ cytokine expression is regulated in CNS injury (Logan et al., 1992). If this applies to the BMPs as well, this major TGF $\beta$ subclass may regulate the expanded repertoire of astroglial phenotypes generated in the pathologically altered CNS environment.

\section{REFERENCES}

Anderson DJ (1989) The neural crest cell lineage problem: neuropoiesis? Neuron 3:1-12.

Barres BA, Raff MC (1994) Control of oligodendrocyte number in the developing rat optic nerve. Neuron 12:935-942.

Cameron RS, Rakic P (1991) Glial cell lineage in the cerebral cortex: a review and synthesis. Glia 4:124-137.

Curtis R, Cohen J, Fok-Seang J, Hanley MR, Gregson NA, Reynolds R, Wilkin GP (1988) Development of macroglial cells in rat cerebellum. I. Use of antibodies to follow early in vivo development and migration of oligodendrocytes. J Neurocytol 17:43-54.

D’Alessandro JS, Wang EA (1994) Bone morphogenetic proteins inhibit proliferation, induce reversible differentiation and prevent cell death in astrocyte lineage cells. Growth factors 11:45-52.

D’Alessandro JS, Yetz-Aldape J, Wang EA (1994) Bone morphogenetic proteins induce differentiation in astrocyte lineage cells. Growth Factors 11:53-69.

Dudley AT, Lyons KM, Robertson EJ (1995) A requirement for bone morphogenetic protein-7 during development of the mammalian kidney and eye. Genes Dev 9:2795-2807.

Flanders KC, Ludecke G, Engels S, Cissel DS, Roberts AB, Kondaiah P, Lafyatis R, Sporn MB, Unsicker K (1991) Localization and actions of transforming growth factor-betas in the embryonic nervous system. Development 113:183-191.

Franklin RJ, Blakemore WF (1995) Glial-cell transplantation and plasticity in the O-2A lineage implications for CNS repair. Trends Neurosci 18:151-156.

Gard AL, Pfeiffer SE (1989) Oligodendrocyte progenitors isolated directly from developing telencephalon at a specific phenotypic stage: myelinogenic potential in a defined environment. Development 106:119-132.

Gard AL, Williams WC, Burrell MR (1995) Oligodendroblasts distinguished from O-2A glial progenitors by surface phenotype $\left(\mathrm{O}^{+} \mathrm{GalC}^{-}\right)$ and response to cytokines using signal transducer LIFR $\beta$. Dev Biol 167:596-608.

Gensert JM, Goldman JE (1996) In vivo characterization of endogenous proliferating cells in adult rat subcortical white matter. Glia 17:39-51.

Godfraind C, Friedrich VL, Holmes KV, Dubois-Dalq M (1989) In vivo analysis of glial cell phenotypes during a viral demyelinating disease in mice. J Cell Biol 109:2405-2416.

Goldman JE, Geier S, Hirano M (1986) Differentiation of astrocytes and 
oligodendrocytes from germinal matrix cells in primary culture. J Neurosci 6:52-60.

Graham A, Francis-West P, Brickell P, Lumsden A (1994) The signalling molecule BMP4 mediates apoptosis in the rhombencephalic neural crest. Nature 372:684-686.

Gross RE, Mehler MF, Mabie PC, Zang Z, Santschi L, Kessler JA (1996) Bone morphogenetic proteins promote astroglial lineage commitment by mammalian subventricular zone progenitor cells. Neuron 17:595-606.

Hannon GJ, Beach D (1994) p15INK4B is a potential effector of TGF $\beta$ induced cell cycle arrest. Nature 371:257-260.

Harland RM (1994) The transforming growth factor beta family and induction of the vertebrate mesoderm: bone morphogenetic proteins are ventral inducers. Proc Natl Acad Sci USA 91:10243-10246.

Hogan BL (1996) Bone morphogenetic proteins: multifunctional regulators of vertebrate development. Genes Dev 10:1580-1594.

Hosoya T, Takizawa K, Nitta K, Hotta Y (1995) Glial cells missing: a binary switch between neuronal and glial determination in Drosophila. Cell 82:1025-1036.

Hughes S, Lillien LE, Raff MC, Rohrer H, Sendtner M (1988) Ciliary neurotrophic factor induces type 2 astrocyte differentiation in culture. Nature 335:70-73.

Jan YN, Jan LY (1995) Maggot's hair and bug's eye: role of cell interactions and intrinsic factors in cell fate specification. Neuron 14:1-5.

Jones BW, Fetter RD, Tear G, Goodman CS (1995) Glial cells missing: a genetic switch that controls glial versus neuronal fate. Cell 82:1013-1023.

Jones CM, Lyons KM, Hogan BL (1991) Involvement of bone morphogenetic protein-4 and Vgr-a in morphogenesis and neurogenesis in the mouse. Development 111:531-542.

Kingsley DM (1994) The TGF $\beta$ superfamily: new members, new receptors, and new genetic tests of function in different organisms. Genes Dev 8:133-146.

Letsou A, Arora K, Wrana JL, Simin K, Twombly V, Jamal J, StaehlingHampton K, Hoffmann FM, Gelbart WM, Massague J, O'Connor MB (1995) Drosophila dpp signaling is mediated by the punt gene product: a dual ligand-binding type II receptor of the TGF $\beta$ receptor family. Cell 80:899-908.

Levison SW, Goldman JE (1993) Both oligodendrocytes and astrocytes develop from progenitors in the subventricular zone of postnatal rat forebrain. Neuron 10:201-212.

Liem KF, Tremmi G, Roelink H, Jessell TM (1995) Dorsal differentiation of neural plate cells induced by BMP-mediated signals from epidermal ectoderm. Cell 82:969-979.

Lillien LE, Raff M (1990) Differentiation signals in the CNS: type 2 astrocyte development in vitro as a model system. Neuron 5:110-119.

Lillien LE, Sendtner M, Raff MC (1990) Extracellular matric-associated molecules collaborate with ciliary neurotrophic factor to induce type-2 astrocyte development. J Cell Biol 111:635-644.

Logan A, Frautschy SA, Gonzalez AM, Sporn M, Baird A (1992) Evidence of endogenous regulatory function of transforming growth factorbeta 1 in experimental allergic encephalomyelitis. Brain Res 587:216-225.

Lois C, Alvarez-Buylla A (1993) Proliferating subventricular zone cells in the adult mammalian forebrain can differentiate into neurons and glia. Proc Natl Acad Sci USA 90:2074-2077.

Lubetzki C, Goujet-Zalc C, Demerens C, Danos O, Zalc B (1992) Clonal segregation of oligodendrocytes and astrocytes during in vitro differentiation of glial progenitor cells. Glia 6:289-300.

Luo G, Hofmann C, Bronckers AL, Sohocki M, Bradley A, Karsenty G (1995) Bmp-7 is an inducer of nephrogenesis, and is also required for eye development and skeletal patterning. Genes Dev 9:2808-2820.

Luskin MB, Pearlman A, Sanes JR (1988) Cell lineage in the cerebral cortex of mouse studied in vivo and in vitro with a recombinant retrovirus. Neuron 1:635-647.

McCarthy KD, DeVellis J (1980) Preparation of separate astroglial and oligodendroglial cell cultures from rat cerebral tissue. J Cell Biol 85:890-902.

Mishina Y, Susuki A, Ueno N, Behringer RR (1995) BMPr encodes a type I bone morphogenetic protein receptor that is essential for gastrulation during mouse embryogenesis. Genes Dev 9:3027-3037.
Norton WT, Farooq M, Chiu FC, Bottenstein JE (1988) Pure astrocyte cultures derived from cells isolated from mature brain. Glia 1:403-414.

Perides G, Safran RM, Downing LA, Charness ME (1994) Regulation of neural cell adhesion molecule and L1 by the transforming growth factor-beta superfamily. Selective effects of the bone morphogenetic proteins. J Biol Chem 269:765-770.

Poulsen KT, Armanini MP, Klein RD, Hynes MA, Phillips HS, Rosenthal A (1994) TGF beta 2 and TGF beta 3 are potent survival factors for midbrain dopaminergic neurons. Neuron 13:1245-1252.

Price J, Thurlow L (1988) Cell lineage in the rat cerebral cortex: a study using retroviral-mediated gene transfer. Development 104:473-482.

Raff MC (1989) Glial cell diversification in the rat optic nerve. Science 243:1450-1455.

Raff MC, Miller RH, Noble M (1983) A glial progenitor cell that develops in vitro into an astrocyte or oligodendrocyte depending on culture medium. Nature 303:390-396.

Reissmann E, Ernsberger U, Francis-West PH, Rugeger D, Brickell PM, Rohrer H (1996) Involvement of bone morphogenetic protein-4 and bone morphogenetic protein-7 in the differentiation of the adrenergic phenotype in developing sympathetic neurons. Development 122:2079-2088.

Reynolds BA, Weiss S (1992) Generation of neurons and astrocytes from isolated cells of the adult mammalian central nervous system. Science 255:1707-1710.

Rosenzweig BL, Imamura T, Okadome T, Cox GN, Yamashita H, ten Dijke P, Heldin CH, Miyazono K (1995) Cloning and characterization of a human type II receptor for bone morphogenetic proteins. Proc Natl Acad Sci USA 92:7632-7636.

Ruberte E, Marty T, Nellen D, Affolter M, Basler K (1995) An absolute requirement for both the type II and type I receptors, punt and thick veins, for dpp signaling in vivo. Cell 80:889-897.

Sasai Y, Lu B, Steinbeisser H, DeRobertis EM (1995) Regulation of neural induction by the Chd and Bmp-4 antagonistic patterning signals in Xenopus. Nature 376:333-336.

Schluesener HJ, Meyermann R (1994) Expression of BMP-6, a TGFbrelated morphogenetic cytokine, in rat radial glial cells. Glia 12:161-164.

Shah NM, Marchionni MA, Isaacs I, Stroobant P, Anderson DJ (1994) Glial growth factor restricts mammalian neural crest stem cells to a glial fate. Cell 77:349-360.

Shah NM, Groves AK, Anderson DJ (1996) Alternative neural crest cell fates are instructively promoted by $\operatorname{TGF} \beta$ superfamily members. Cell 85:331-343.

Skoff RP, Knapp PE (1991) Division of astroblasts and oligodendroblasts in postnatal rodent brain: evidence for separate astrocyte and oligodendrocyte lineages. Glia 4:165-174.

Temple S, Raff MC (1985) Differentiation of a bipotential glial progenitor cell in single cell microculture. Nature 313:223-225.

ten Dijke P, Franzen P, Yamashita H, Ichijo H, Heldin CH, Miyazono K (1994a) Serine/threonine kinase receptors. Prog Growth Factor Res 5:55-72.

ten Dijke P, Ichijo H, Franzen P, Schulz P, Saras J, Toyoshima H, Heldin CH, Miyazono K (1994b) Activin receptor-like kinases: a novel subclass of cell-surface receptors for BMP-2 and BMP-4 from NIH 3T3 cells. Mol Cell Biol 14:5961-5974.

ten Dijke P, Yamashita H, Sampath TK, Reddi AH, Estevez M, Riddle DL, Ichijo H, Heldin CH, Miyazono K (1994c) Identification of type I receptors for osteogenic protein-1 and bone morphogenetic protein-4. J Biol Chem 269:16985-16988.

Wilson PA, Hemmati-Brivanlou A (1995) Induction of epidermis and inhibition of neural fate by Bmp-4. Nature 376:331-333.

Winnier G, Blessing M, Labosky PA, Hogan BL (1995) Bone morphogenetic protein-4 is required for mesoderm formation and patterning in the mouse. Genes Dev 9:2105-2116.

Wolswijk G, Noble M (1992) Cooperation between PDGF and FGF converts slowly dividing $\mathrm{O}-2 \mathrm{~A}$ adult progenitor cells to rapidly dividing cells with characteristics of $\mathrm{O}-2 \mathrm{~A}$ perinatal progenitor cells. J Cell Biol 118:889-900. 